Aneta Kaźmierska-Patrzyczna

Uniwersytet Łódzki

Katarzyna Kaźmierska-Stępniak

Uniwersytet Łódzki

\title{
ROLA SYSTEMU EKOZARZADZZANIA I AUDYTU EMAS W REALIZACJI ZRÓWNOWAŻONEGO ROZWOJU
}

\section{Wprowadzenie}

W obecnej rzeczywistości gospodarczej coraz częściej przedsiębiorstwa podejmują czynności zmierzające do przeciwdziałania zjawisku pogarszania się stanu środowiska naturalnego, poprzez dążenie do pełnej integracji stosunków gospodarczych ze stosunkami ekologicznymi, wprowadzania tzw. ekologicznej gospodarki rynkowej, dzięki wkomponowaniu wymogów zrównoważonego rozwoju do tworzonych rozwiązań prawnych oraz do nowego systemu zarządzania. ${ }^{1}$ Wielu ekspertów uważa, że przedsiębiorstwa wchodzą w tzw. fazę ekologiczną. ${ }^{2}$ Przedsiębiorstwo bowiem powinno być organizacją służącą otoczeniu, oprócz zadań ekonomicznych realizuje także zadania społeczne, w tym ekologiczne. Przedsiębiorstwo musi być więc organizacją odpowiedzialną społecznie, a co za tym idzie musi dbać o ochronę środowiska i to bez względu na wielkość, rodzaj działalności i lokalizację. Nowy rynek gospodarczy wymaga od przedsiębiorcy stworzenia systemowych rozwiązań w modelu zarządzania pozwalających połączyć potrzeby ochrony środowiska z praktyką gospodarczą w sposób skuteczny i efektywny ze społecznego punktu widzenia. ${ }^{3}$ Nowoczesne podejście do wypracowania polityki ekologicznej musi opierać się na zasadach zrównoważonego rozwoju, zakładać poprawę jakości życia obywateli poprzez zapewnienie im bezpieczeństwa ekologicznego. Coraz powszechniejsze staje się stosowanie różnych sformalizowanych systemów zarządzania.

\footnotetext{
1 Szerzej na ten temat K. Górka, Instrumenty polityki ekologicznej w Polsce, (w:) K. Górka (red.), Polityka ekologiczna w ujęciu makroekonomicznym oraz regionalnym, Kraków 1993, s. 9.

2 Szerzej na ten temat J. Penc, Strategie zarządzania, cz. 2, Warszawa 1999, s. 159-160.

3 Szerzej na ten temat M. Burchard-Dziubińska, Ekologiczne i ekonomiczne aspekty restrukturyzacji przemysłu, Białystok 1998, s. 7-14.
} 
Wspólnotowy instrument prawa ochrony środowiska - system ekozarządzania i audytu EMAS stanowi nowoczesną metodę zarządzania, ukierunkowaną na osiąganie celów ochrony środowiska. Pozwala organizacjom w pełni nadzorować wpływ na środowisko i uwzględniać ich bezpośrednie i pośrednie aspekty środowiskowe w kierowaniu działalnością organizacji. Jest połączeniem ekonomicznego narzędzia zarządzania z regulacjami prawnymi, co przynosi efekty w obszarze ochrony środowiska. System ekozarządzania jest doskonałym przykładem wykorzystania, z jednej strony niewładczych i dobrowolnych narzędzi prawnych w stymulowaniu rozwoju ekonomicznego oraz ekologicznego, a z drugiej strony roli teorii jakości w tworzeniu prawa Unii Europejskiej. System ekozarządzania i audytu (EMAS) jest najbardziej zaawansowanym systemem zarządzania środowiskowego, jaki mogą wdrażać organizacje. System ekozarządzania i audytu EMAS w porównaniu do innych systemów zarządzania środowiskowego (norm ISO 14001) reprezentuje bardziej zinstytucjonalizowane podejście do zarządzania środowiskowego $\mathrm{z}$ uwagi na to, że w tworzenie jego rejestru włączone są organy administracji publicznej. To z kolei przyczynia się do tego, że organizacje przywiązują dużą wagę do spełniania i przestrzegania środowiskowych standardów prawnych.

System ekozarządzania i audytu (EMAS) to instrument realizacji polityki ekologicznej Unii Europejskiej, którego zadaniem jest informowanie opinii publicznej o zagadnieniach związanych z ochroną środowiska, poprzez raporty środowiskowe (tzw. deklaracje EMAS). System w założeniu ma stanowić skuteczne narzędzie Rady i Parlamentu Unii Europejskiej służące minimalizacji oddziaływań środowiskowych różnego rodzaju organizacji i wzmocnieniu ich proekologicznego kierunku rozwoju. Ponadto ma dostarczać społeczeństwu i grupom zainteresowanych stosownych informacji oraz promować ciągłe doskonalenie działalności środowiskowej. ${ }^{4}$ Zatem system EMAS jest elementem wspomagającym przedsiębiorstwa w realizacji zasad zrównoważonego rozwoju.

Polityka ekologiczna Państwa na lata 2009-2012 z perspektywą do roku 2016 na polu aktywacji rynku na rzecz ochrony środowiska, uwzględniła uruchomienie takich mechanizmów prawnych, ekonomicznych i edukacyjnych, które prowadziłyby do rozwoju proekologicznej produkcji towarów oraz do świadomych postaw konsumenckich zgodnie z zasadą zrównoważonego rozwoju..$^{5}$ Aby idea zrównoważonego rozwoju stała się powszechnym trendem należy nie tylko zadbać o systematyczne podnoszenie świadomości zarządu firm, ale także o edukację całego społeczeństwa. Ważnym staje się większe zaangażowanie instytucji państwowych, samorządowych, a także środowiska naukowego w promowaniu tej idei, a także systemu zarządzania środowiskowego.

5
Szerzej na ten temat J. Łunarski (red.), Systemy zarządzania środowiskowego, Rzeszów 2009, s. 46 i n.

Polityka ekologiczna Państwa w latach 2009-2012 z perspektywą do roku 2016, Zarządzania Środowiskowe, cele średniookresowe do 2016 r., Ministerstwo Środowiska, Warszawa 2008, s. 16. 
W Polityce Ekologicznej na lata 2009-2012 zostały również określone cele średniookresowe do 2016 r. w odniesieniu do zarządzania środowiskiem. Jest to m.in. przystępowanie organizacji do systemu EMAS w jak najszerszy sposób, rozpowszechnianie wiedzy wśród społeczeństwa o tym systemie oraz o tworzeniu korzyści ekonomicznych dla firm i organizacji będących w systemie. W omawianym dokumencie strategicznym wyznaczono również kierunki działań zmierzających do upowszechnienia systemu EMAS. Jako kierunek działań wyznaczono upowszechnianie wśród społeczeństwa wizerunku logo EMAS i normy ISO 14001, a także CP (Czystej Produkcji) - znaków wskazujących na utrzymanie jakości środowiskowej w danym przedsiębiorstwie. Założono także podniesienie prestiżu instytucji publicznych posiadających certyfikat zarządzania środowiskowego poprzez promowanie systemu zarządzania środowiskowego wśród społeczeństwa. Ponadto zaproponowano też ograniczenie kosztów związanych z wdrożeniem systemów zarządzania środowiskowego, a dla organizacji posiadających systemy zarządzania środowiskowego ograniczenie częstotliwości kontroli w zakresie ochrony środowiska.

\section{Funkcjonowanie Systemu Ekozarządzania i Audytu (EMAS)}

System ekozarządzania i audytu EMAS do wspólnotowego porządku prawnego został wprowadzony rozporządzeniem Rady 1836/93 z dnia 29 czerwca 1993 r. w sprawie dobrowolnego uczestnictwa firm przemysłowych w systemie zarządzania ochrony środowiska i przeglądów ekologicznych we Wspólnocie (EMAS I), które weszło w życie 13 lipca 1993 r. $^{6}$

Podstawą dla wprowadzenia systemu były założenia przyjęte w Piątym Programie Działań Środowiskowych (lata 1993-2000) - Ku trwałemu rozwojowi (,, W kierunku zrównoważonego wzrostu” „Towards Sustainability”). ${ }^{7}$ Program podkreślał, iż rolą i obowiązkiem przedsiębiorstw jest nie tylko rozwijanie gospodarki wspólnotowej, ale również ochrona środowiska. Ponadto wzywał do rozszerzenia zakresu stosowanych instrumentów w dziedzinie ochrony środowiska oraz do wykorzystywania mechanizmów rynkowych w celu zobowiązania organizacji do przyjęcia w tej dziedzinie podejścia aktywnego, wykraczającego poza zapewnienie zgodności ze wszystkimi odpowiednimi wymaganiami prawnymi odnoszącymi się do środowiska. ${ }^{8} \mathrm{~W}$ programie uznano potrzebę ,ujednolicenia kontroli zanieczyszczeń” i założono, że zadania przedsiębiorstw i ich odpowiedzialność w zakresie ochrony środowiska powinna zostać wzmocniona. Program podkreślał zwłaszcza rolę, jaką

$6 \quad$ OJ L161, 2.07.1993, p. 4. Tekst aktu został opublikowany po polsku - Prawo Ochrony Środowiska Wspólnoty Europejskiej, Instytut Ochrony Środowiska, Warszawa 1997, suplement 1.

7 Przyjęty na mocy uchwały Rady i Przedstawicieli Rządów Państw Członkowskich obradujących jako Rada 1 lutego 1993 r. nad programem Wspólnoty dotyczącym polityki i działań odnoszących się do środowiska naturalnego i zrównoważonego rozwoju (Dz. Urz. WE, C138, 17.05.1993).

$8 \quad$ Zob. B. Poskrobko (red.), Zarządzanie środowiskiem, Warszawa 2007, s. 274; A. Konderski (red.), Ochrona środowiska dla Małych i Średnich Przedsiębiorstw, Gdańsk 2006, s. 10. 
przedsiębiorstwa, zarówno publiczne jak i prywatne, mają do spełnienia w zakresie ochrony środowiska zwracając uwagę, iż w znacznej mierze to właśnie one są odpowiedzialne za naruszenie wymogów ochrony środowiska. ${ }^{9}$

Bardzo istotne zmiany w stosunku do systemu EMAS I, podlegającego regulacji rozporządzenia 1836/93, wprowadziło nowe rozporządzenie $761 / 2001 .{ }^{10} \mathrm{~W}$ celu zwiększenia udziału przedsiębiorstw w systemie oraz osiągnięcia większej akceptacji wszystkich zainteresowanych stron (m.in. przedsiębiorstw, klientów, partnerów handlowych), nowe rozporządzenie EMAS II dopuszczało w nim udział także organizacji pozaprzemysłowych oraz doprowadziło do zharmonizowania systemów, w wyniku czego nastąpiła tzw. kompatybilność EMAS i ISO 14001. Zmiany wprowadzone do systemu EMAS II rozporządzeniem 761/2001 zwiększyły korzyści związane $\mathrm{z}$ wdrożeniem samego systemu EMAS ${ }^{11} \mathrm{w}$ porównaniu z innymi systemami zarządzania środowiskowego oraz spowodowały konieczność udoskonaleń w zakresie ochrony środowiska w przedsiębiorstwach poprzez regularne kontrole oraz sprawozdania, jak również kontrolowanie procesu przestrzegania wymogów EMAS w krótszych odstępach czasowych, połączone z większym nadzorem weryfikatorów środowiskowych.

Obecnie obowiązuje rozporządzenie Parlamentu Europejskiego i Rady (WE) nr 1221/2009 z dnia 25 listopada 2009 r. w sprawie dobrowolnego udziału organizacji w systemie ekozarządzania i audytu we Wspólnocie (EMAS), uchylające rozporządzenie (WE) nr 761/2001 oraz decyzje Komisji 2001/681/WE i 2006/193/WE. ${ }^{12}$ Rozporządzenie EMAS III zobowiązało Polskę, jako państwo członkowskie UE, do zmiany dotychczas obowiązującej ustawy EMAS, ${ }^{13}$ albowiem funkcjonujący na jej podstawie system nie zapewniał faktycznej realizacji postanowień rozporządzenia $1221 / 2009$.

Nowa ustawa o krajowym systemie ekozarządzania i audytu EMAS ${ }^{14} \mathrm{z}$ dnia 15 lipca 2011 r., która weszła w życie 29 września 2011 r., dokonała uproszczenia struktury organizacyjnej systemu ekozarządzania i audytu EMAS w Polsce, pozostawiając jedynie rejestr EMAS (poprzednio zwany rejestrem krajowym) organizacji zarejestrowanych w systemie, prowadzony przez Generalnego Dyrektora Ochrony Środowiska (GDOŚ), jednocześnie likwidując rejestr regionalny prowadzony przez

9 M. Górski, System EMAS w polskim porządku prawnym, (w:) J. Ejdys (red.), Wybrane aspekty zarządzania wiedzą w organizacji, Poznań 2005, s. 172.

10 Rozporządzenie (WE) nr 761/2001 Parlamentu Europejskiego i Rady z dnia 19 marca 2001 r. dotyczące dobrowolnego uczestnictwa organizacji w systemie ekozarządzania i audytu we Wspólnocie (Dz. Urz. UE L. 114, 24 kwietnia 2001 r., s. 1), dalej powoływane jako rozporządzenie EMAS II.

11 M. Szydłowski, Wprowadzenie w Polsce systemu EMAS oraz pozwoleń zintegrowanych, (w:) A. Wasiak, G. Dobrzański (red.), Zrównoważony rozwój w przedsiębiorstwie i jego otoczeniu, Białystok 2005, s. 133-134.

12 Dz. Urz. WE L 09.342.1 z dnia 22 grudnia 2009; dalej powoływane jako rozporządzenie EMAS III lub rozporządzenie 1221/2009.

13 Ustawa z dnia 12 marca 2004 r. o krajowym systemie ekozarządzania i audytu (EMAS) (Dz.U. Nr 70, poz. 631 ze zm.).

14 Ustawa z dnia 15 lipca 2011 r. o krajowym systemie ekozarządzania i audytu (EMAS) (Dz.U. Nr 178, poz. 1060 ze zm.); dalej powoływana jako ustawa o EMAS z dnia 15 lipca $2011 \mathrm{r}$. 
Regionalnych Dyrektorów Ochrony Środowiska (RDOŚ). Obecnie RDOŚ uczestniczą w opiniowaniu wniosków jako organy podlegające GDOŚ, a całość procesu rejestracji jest prowadzona przez GDOŚ. Ponadto na mocy nowej ustawy z systemu EMAS została usunięta Krajowa Rada Ekozarządzania (KRE). Obecnie system EMAS w Polsce działa w oparciu o strukturę organizacyjną, którą tworzą:

- Minister właściwy do spraw środowiska;

- Generalny Dyrektor Ochrony Środowiska;

- Polskie Centrum Akredytacji.

\section{Korzyści z wdrażania systemu EMAS}

Zainteresowanie problematyką ochrony środowiska wciąż wzrasta, zarówno wśród przedsiębiorstw funkcjonujących w różnych branżach gospodarki, jak również jednostek samorządu terytorialnego, czy administracji rządowej. Z każdym rokiem zwiększa się liczba różnych organizacji wdrażających sformalizowany system zarządzania środowiskowego, co świadczy o docenieniu efektów jego funkcjonowania.

Wprowadzenie systemu zarządzania środowiskiem usprawnia zarządzanie ryzykiem, a więc wpływa na zmniejszenie prawdopodobieństwa wystąpienia awarii i wypadków oraz zminimalizowanie ich ewentualnych skutków i to dzięki przygotowanym wcześniej procedurom postępowania w sytuacjach awaryjnych. Ryzyko środowiskowe jest istotnym elementem wpływającym na decyzję o podjęciu współpracy lub zaangażowaniu się w proces decyzyjny. Pomimo iż przypadki wstrzymania działalności ze względu na ich negatywne oddziaływanie na środowisko należą do rzadkości, to zablokowanie inwestycji w związku z brakiem akceptacji uwarunkowań środowiskowych należą do coraz częstszych zdarzen. ${ }^{15}$ Funkcjonowanie w organizacji systemu zarządzania środowiskowego pociąga za sobą wiele korzyści niemających charakteru finansowego. ${ }^{16}$ Do tych korzyści ${ }^{17}$ związanych z wdrożeniem systemu zarządzania środowiskowego należy zaliczyć fakt, że wdrożenie zasad zarządzania środowiskowego może prowadzić do zmniejszenia częstotliwości kontroli środowiskowych prowadzonych przez administrację publiczną oraz złagodzenia innych form nadzoru.

15 Przedsiębiorstwa, które uruchamiają nową inwestycję, są zobowiązane do przeprowadzenia oceny oddziaływania tej inwestycji na środowisko, zgodnie z ustawą z dnia 3 października 2008 r. o udostępnianiu informacji o środowisku i jego ochronie, udziale społeczeństwa w ochronie środowiska oraz o ocenach oddziaływania na środowisko (Dz.U. Nr 199, poz. 1227 ze zm.). Zob. również: A. Matuszak-Flejszman, Benefits of Environmental Management System compliant with ISO 14001 standard in Polish companies, „Polish Journal of Environmental Studies" 2009, nr 3.

16 Szerzej na ten temat: B. Poskrobko, Zarządzanie środowiskiem..., op. cit., s. 295.

17 Szerzej na ten temat: P. Grudowski, Jakość, środowisko i bhp w systemach zarządzania, Bydgoszcz 2003, s. 101-102. 
Skuteczność systemów zarządzania środowiskowego w osiąganiu założonych korzyści była poddawana wielu badaniom. Poprzednio obowiązujące rozporządzenie 761/2001, zobowiązało Komisję do dokonania przeglądu EMAS w świetle doświadczeń zdobytych $\mathrm{w}$ trakcie jego stosowania. ${ }^{18} \mathrm{~W}$ tym kontekście $\mathrm{w} 2005 \mathrm{r}$. przeprowadzono szeroką ocenę systemu EMAS. Ocena, wraz z informacjami otrzymanymi od różnych zainteresowanych stron uczestniczących w systemie, pozwoliła na określenie mocnych i słabych punktów systemu ekozarządzania. W wyniku przeprowadzonej oceny EVER ${ }^{19}$ wskazano na korzyści wynikające $\mathrm{z}$ wdrożenia systemu ekozarządzania i audytu. System EMAS został uznany za środek umożliwiający włączenie kwestii związanych ze środowiskiem do wspólnego systemu wartości organizacji, mogący przyczynić się do poprawy jej wizerunku. Ponadto system ekozarządzania jest postrzegany nie tylko jako system pozwalający na zmniejszenie kosztów usuwania odpadów, zużycia energii, ale jest również sygnałem troski o środowisko. Usprawnienia w dziedzinie ochrony środowiska, lepszy wizerunek i niższe koszty postrzegane są jako najważniejsze korzyści płynące z wdrożenia systemu ekozarządzania i audytu. Co warto podkreślić, chociaż prawie połowa badanych oceny EVER wskazała, że koszty finansowe wdrażania EMAS przeważają nad korzyściami, to ponad dwie trzecie respondentów uznało EMAS za sukces po dokonaniu porównania finansowych i niefinansowych korzyści i kosztów. Wyniki projektu REMAS realizowanego w latach 2002-2006 wykazały, iż wdrożenie i utrzymanie certyfikowanego systemu zarządzania środowiskowego przyczynia się nie tylko do poprawy zarządzania środowiskowego obiektu, ale wdrożony system EMAS jest korzystniejszy od innych systemów zarządzania środowiskowego. Organizacje posiadające certyfikat ISO 14001 chcąc zwiększyć przejrzystość działania z zainteresowanymi stronami wnoszą o rejestrację w systemie ekozarządzania.

Badania przeprowadzone wśród polskich przedsiębiorstw, które wdrożyły system EMAS, wskazywały, iż dla większości organizacji kategoria korzyści niematerialnych jest znacząca. ${ }^{20}$ Poprawa wizerunku ekologicznego, poprzez wzmocnienie stosunków z podmiotami zewnętrznymi, jest dla wszystkich organizacji funkcjonujących w warunkach gospodarki rynkowej i silnej konkurencji szczególnie istotna. System EMAS ma na celu zwiększenie możliwości skutecznej komunikacji z opinią publiczną oraz innymi zainteresowanymi stronami, w celu zwiększenia przejrzystości i wiarygodności oraz poprawy wizerunku organizacji. Badania REMAS wska-

18 W rozporządzeniu 761/2001 stanowił o tym art. 15. Obecnie obowiązuje art. 50 rozporządzenia 1221/2009, który zobowiązuje Komisję do dokonania przeglądu EMAS do dnia 11 stycznia $2015 \mathrm{r}$.

19 Zob. Wniosek - Rozporządzenie Parlamentu Europejskiego i Rady dotyczące dobrowolnego udziału organizacji w systemie ekozarządzania i audytu we Wspólnocie (EMAS) COM(2008) 402 wersja ostateczna - 2008/0154 (COD).

20 J. Ejdys, Metoda oceny wyników działalności środowiskowej, Białystok 2004, s. 38. Wśród korzyści płynących z wdrożenia i utrzymania systemu ekozarządzania w głównej mierze przedsiębiorstwa dostrzegają poprawę wizerunku $(88,9 \%)$ oraz zwiększenie sprawności i przejrzystości działań związanych ze środowiskiem (70,9\%), zob. W. Łuczka-Bakuła, Skutki systemu zarządzania środowiskowego według normy ISO 14001 i EMAS, „Roczniki Ekonomiczne Kujawsko-Pomorskiej Szkoły Wyższej w Bydgoszczy" 2009, nr 2, s. 111-123. 
zują, że system ekozarządzania wpływa na poprawę relacji z organami właściwymi w większym stopniu niż z jakąkolwiek inną zainteresowaną stroną. Rejestracja w systemie przyczyniła się do wzrostu zaufania między organizacją i właściwymi organami, co skraca czas monitorowania na zgodność z przepisami prawa i jest postrzegane jako kolejna kluczowa zachęta we wdrożeniu systemu EMAS.

$\mathrm{Z}$ badań opublikowanych w raporcie Study on the Costs and Benefits of EMAS to Registered Organisations ${ }^{21}$ wynika, iż dodatkowe wymagania wynikające z systemu ekozarządzania i audytu EMAS mają przełożenie na specyficzne korzyści. Jedną z najważniejszych korzyści wdrożenia i funkcjonowania systemu EMAS jest zapewnienie zgodności z obowiązującymi przepisami prawnymi ochrony środowiska, ${ }^{22}$ co z kolei skutkuje uzyskaniem większej wiarygodności wśród inwestorów, klientów, jak również władz administracyjnych i organów kontrolnych. Ponadto publikowanie informacji o efektach starań dotyczących ograniczenia wpływu na środowisko naturalne pomaga stworzyć korzystny wizerunek przedsiębiorstwa w społeczeństwie, a dzięki temu wpływa pozytywnie na jego pozycję rynkową. Deklaracja środowiskowa jest bowiem narzędziem służącym do zwiększenia dostępu społeczeństwa do informacji. Jak wskazuje W. Adamczyk ${ }^{23}$ obowiązkowe publikowanie raportów środowiskowych pozwala konsumentom na łatwe skojarzenie działań proekologicznych, podejmowanych przez przedsiębiorstwo, z wyrobem lub usługą. Stanowi to efekt promocji dla proekologicznych działań i wyrobów . Tak więc, wdrożenie systemu ekozarządzania i audytu przyczynia się do poprawy relacji przedsiębiorstwa z konsumentami, gdzie kryteria ekologiczne są coraz częściej jednym z czynników decyzji zakupowych. ${ }^{24}$

Wspomniane możliwości zwiększonej wydajności kosztów własnych, ograniczenie negatywnych zdarzeń, poprawa stosunków z właściwymi organami, a także $\mathrm{z}$ innymi zainteresowanymi stronami, tworzą warunki do ugruntowania lub poprawy pozycji rynkowej. Wdrożony i utrzymany system ekozarządzania oznacza, że organizacja posiada sprawny system zarządzania środowiskowego, co może stać się ważnym argumentem w występowaniu o zamówienia publiczne. ${ }^{25}$

21 Badania przeprowadzone przez Milieu Ltd and Risk and Policy Analysis Ltd for DG Environment of the European Commission. Źródło: Study on the Costs and Benefits of EMAS to Registered Organizations, Study Contract No. 07.0307/2008/517800/ETU/G.2, October, 2009, s.12.

22 Wyniki działań kontrolnych Inspekcji Ochrony Środowiska wskazują, że w 2004 r. w ok. 70\% kontrolowanych przedsiębiorstw stwierdzono naruszenie przepisów z zakresu gospodarki odpadami, $75 \%$ przepisów z zakresu odprowadzania ścieków, 69\% w zakresie obowiązków związanych z substancjami i preparatami chemicznymi, a w ponad $57 \%$ w sferze ochrony środowiska z procesie inwestycyjnym, zob. B. Poskrobko, Zarządzanie środowiskiem..., op. cit., s. 296.

23 Zob. W. Adamczyk, Ekologia wyrobów, Warszawa 2004, s. 52-53.

24 H. Jastrzębska-Smolaga, W kierunku trwałej konsumpcji. Dylematy, zagrożenia, szanse, Warszawa 2000, s. 20.

25 Wdrożenie systemu EMAS traktowane jako kryterium w zamówieniach publicznych zostało wzmocnione poprzez realizację Dyrektyw 2004/17/WE i 2004/18/WE w sprawie zamówień publicznych. Większość państw członkowskich faworyzuje organizacje, które posiadają system zarządzania środowiskowego, w przypadku podejmowania decyzji w sprawie zamówień publicznych poprzez przyznawanie dodatkowych punktów dla zarejestrowanych organizacji w procesie oceny ofert/oferentów na podstawie określonych kryteriów. Źródło: Study on the Costs..., op. cit., s.12; http://ec.europa.eu/environment/emas/pdf/news/costs_and_benefits_of_emas.pdf (data dostępu: 20.03.2011 r.). 
Podsumowując przedstawione uwagi trzeba stwierdzić, iż istotną rolę w organizacji odgrywa wymóg rozporządzenia 1221/2009 dotyczący spełnienia wymagań prawnych w zakresie przestrzegania prawa ochrony środowiska. Obowiązek ten pozwala organizacji uniknąć potencjalnych kar pieniężnych, a co za tym idzie niekorzystnego wizerunku związanego $\mathrm{z}$ łamaniem przepisów ochrony środowiska przez organizację. Wiedza $\mathrm{w}$ zakresie wymagań prawnych oraz świadomość proekologiczna kierownictwa i pracowników pomaga organizacjom bardzo często przewidywać wpływy przyszłych wymagań prawnych dotyczących ochrony środowiska. To daje organizacji okazję do zharmonizowania planów rozwoju w celu spełnienia tych wymagań prawnych. ${ }^{26}$

\section{Podsumowanie}

System ekozarządzania i audytu EMAS jako publicznoprawny system ma szansę odegrać ważną rolę w realizacji zrównoważonego rozwoju, gdyż dąży do równowagi między ochroną środowiska a spełnianiem potrzeb społeczeństwa, daje wyraźne korzyści przedsiębiorstwom, organom administracji, społeczności lokalnej, a także społeczeństwu. Mimo korzyści z wdrożenia system EMAS jest w Polsce mało znany, a instytucje państwowe w zasadzie nie preferują przedsiębiorstw, które realizują ideę zrównoważonego rozwoju. Istnieje bowiem wiele barier, które sprawiają, że system EMAS jest mało rozpowszechniony, a mianowicie w niewystarczający sposób prowadzona jest polityka informacyjna dotycząca systemu, dla przykładu logo EMAS, które może być wykorzystywane w materiałach marketingowych jest mało znane w społeczeństwie polskim. Brak jest zachęt ze strony sektora publicznego, który promowałby produkty ekologiczne poprzez dostosowania praktyk zamówień publicznych, ${ }^{27}$ mimo dużej swobody ze strony państw członkowskich. Zbyt małe zaangażowanie instytucji odpowiedzialnych za implementację systemu w zachęcanie do przystąpienia do systemu EMAS organizacji, które już mają system ISO 14001 i zmiany kompetencji odnośnie odpowiedzialności ze strony organów państwowych nie mogły wpłynąć korzystnie na rozpowszechnienie systemu w naszym kraju.

W komunikacie Komisji Europejskiej z dnia 16 lipca 2008 r. dotyczącym planu działania na rzecz zrównoważonej konsumpcji i produkcji oraz polityki przemysłowej uznano, że system ekozarządzania i audytu pomaga organizacjom optymalizować ich procesy produkcyjne dzięki zmniejszeniu ich oddziaływania na środowisko i bardziej wydajnemu wykorzystaniu zasobów. Dlatego, pomimo iż wdrażanie sys-

\footnotetext{
26 Szerzej na ten temat A. Matuszak-Flejszman, Determinanty doskonalenia systemu zarządzania środowiskowego zgodnego z wymaganiami normy ISO 1400, Poznań 2010, s.27-34 i podana tam literatura.

27 Komunikat Komisji Parlamentu Europejskiego, Rady, Europejskiego Komitetu Ekonomiczno-Społecznego oraz Komitetu Regionów dotyczący planu działania na rzecz zrównoważonej konsumpcji i produkcji oraz zrównoważonej polityki przemysłowej, COM 397, 16 lipca 2008.
} 
temu ekozarządzania i audytu EMAS wiąże się z wieloma nakładami ze strony organizacji, nie tylko finansowymi, ale przede wszystkim dotyczącymi zapewnienia zasobów ludzkich czy odpowiedniej infrastruktury i środowiska pracy, to w efekcie są one zneutralizowane przez korzyści, jakie może organizacja osiągnąć w wyniku skutecznie wdrożonego i utrzymywanego systemu ekozarządzania i audytu EMAS. Podejmując decyzję o wdrożeniu systemu EMAS kierownictwo organizacji powinno przede wszystkim być przekonane o korzyściach, jakie organizacja może osiągnąc $\mathrm{w}$ wyniku wdrożenia, utrzymania i doskonalenia systemu ekozarządzania i audytu EMAS. Już na dzień dzisiejszy należy zauważyć, iż nowe rozporządzenie EMAS III i większe zaangażowanie instytucji publicznych, o czym świadczy cykl konferencji w 2010 r. w Polsce, preferowanie firm zarejestrowanych w EMAS w polityce zamówień publicznych, symboliczne opłaty rejestracyjne dla sektora małych i średnich przedsiębiorstw (sektor MPS, organów administracji publicznej, edukacji) doprowadziło do wzrostu zainteresowania implementacją systemu EMAS. Obecnie w krajowym systemie ekozarządzania i audytu zarejestrowane są 43 organizacje, gdzie jeszcze rok temu (dane na czerwiec 2012 r.) system wdrożyły 32 organizacje. ${ }^{28}$ Dla porównania na dzień 29 stycznia 2010 r., we wspólnotowym systemie ekozarządzania i audytu EMAS było zarejestrowanych 19 polskich organizacji oraz 31 obiektów. Ważna pozostaje nadal kwestia ciągłej edukacji społeczeństwa poprzez odpowiednie programy nauczania, środki masowego przekazu, co zaowocuje większym zainteresowaniem i zaangażowaniem pracowników w implementacji systemu EMAS. 


\section{THE ROLE OF THE ECO-MANAGEMENT AND AUDIT SCHEME EMAS IN THE REALIZATION OF SUSTAINABLE DEVELOPMENT}

In the following article the authors present the European Eco-Management and Audit Scheme (EMAS) - an instrument based on voluntary participation which is used to evaluate and improve the effects of a company's environmental activities as well as to provide society and all interested parties with a reliable source of information in this area.

EMAS is a component of a new concept of action which relies on resignation from a prescriptive system in favour of a company's voluntary obligation to comply with all requirements.

EMAS is an effective tool for minimizing the environmental impact of different types of organizations and strengthens the ecological direction of their development. EMAS helps organizations to optimize production processes by reducing their impact on the environment with more efficient use of resources. Furthermore, it provides the public and interested groups with relevant information and promotes continuous improvement in environmental performance.

A goal of applying EMS is not only to lower environmental pressure created by a particular company but also to show that such organization is operating in accordance with the law.

Keywords: sustainable development, environmental protection, EcoManagement and Audit Scheme 